\title{
EQuilibrium
}

Quarterly Journal of Economics and Economic Policy

VOLUME 8 ISSUE 1, 2013

ISSN 1689-765X

Libuše Macáková*

University of Economics, Prague, Czech Republic

\section{Selected Problems of Integration of Foreigners in the Czech Republic}

\section{JEL Classification: $J 15$}

Keywords: integration, immigration, education, health care

\begin{abstract}
The aim of this paper is to characterize the problems of immigration and subsequent integration of foreigners in the Czech Republic. The starting point is a brief historical perspective on the development of migration policies of the Czech Republic and the development of immigration in recent years. The aspects discussed in particular are education and health care, as the main factors affecting the integration of immigrants. The analysis suggests a pivotal role of the state in the activities focused on the integration of foreigners, an important role is played by non-profit organizations. In the end of the paper attention is focused on the Czech public attitude to immigration. Active immigration policy in the Czech Republic began in 2003. Currently, integration is understood as an essential part of the immigration policy of the Government of the Czech Republic. Integration of foreigners into the Czech society is directly linked to the process of immigration and is crucial for the smooth immigrant participation in the local labor market and life in the country. The main problem is the lack of knowledge of the Czech language by adult immigrants and especially their children, lack of knowledge of the Czech language, which significantly complicates the possibility of integration into the Czech society. Access to health care is another critical area of integration.
\end{abstract}

(C) Copyright Polish Economic Society Branch in Torun

Date of Submission: January 22, 2013; date of acceptance: February 25, 2013

* Contact: e-mail: macakova@vse.cz, University of Economics, Prague, W. Churchill Sq. 4, 13067 Prague 3, Czech Republic 
Not all areas of integration are managed entirely ideally. This paper tries to highlight specific partial deficiencies. Further development is possible only after an analysis of the basic factors of integration.

\section{Introduction}

Integration of foreigners is absolutely essential. This follows from the volume of immigration to the Czech Republic, which makes it an obvious need to focus on the integration here. Up to 2008, there was a relentless increase in the number of foreigners coming to the Czech Republic. Since then, due to the global economic crisis in the region a certain decline occurred, not only in the Czech Republic. Despite this decline, however, there is the prospect of renewed growth in global migration. The ability to integrate migrants into the society will be increasingly important. Education is a key factor of integration. Language courses can break down language barriers and thereby enable the integration of people into society. The education of foreigners must not only concentrate on communication, but has to include comprehensive education, especially of the children of foreigners. Children and teenagers are groups that need the most education.

Access to health care is another critical area of integration. It is true that all immigrants have access to health care, the difference here, however, arises in the payment of the care provided. Some groups of immigrants have no access to public health insurance and are forced to pay commercial insurance which often covers emergency care only. Thus, for example, are excluded not only the self-employed, but also children of immigrants without permanent residence in the Czech Republic. Ambiguous provision of care for the health of children of immigrants can be considered as a drawback.

\section{Immigration Policy of the Czech Republic}

The origins of migration policy in the Czech Republic are linked to the period of our territory belonging to Austria-Hungary. "Citizenship, according to the General Civil Code of 1811 was obtained primarily on the basis of citizenship of biological parents. It was also possible to acquire citizenship automatically by embarking on public services, or the establishment of a trade or ten-year stay in the country, but only if during that time the foreigner was not found guilty of a criminal offence. 
Foreigners had the opportunity to apply for citizenship even before the tenyear period based on their assets, earning ability and proper moral behavior. The first Czechoslovak Republic took the view that naturalization was granted as an act of grace from the state, and that view continues till now." (Baršová at al. 2005, p. 211).

The strongest immigration flows always occurred after wars, with the return of original inhabitants who had emigrated because of wars, bad political situation or economic instability. After the end of the 2nd World War, the state supported official resettlement activities, which focused on the Czechs, Slovaks and members of other Slavic nations. This enabled and facilitated the practice of professions and employment appropriate to their current careers. The Soviet-style state socialism which followed (19481989) meant closing borders to the countries outside the socialist bloc. Within the socialist bloc, internal temporary labor migration was supported by the Council for Mutual Economic Assistance. Special long-term cooperation was given to the Socialist Republic of Vietnam. In this framework, Vietnamese citizens were given training in organizations in Czechoslovakia.

Agreements within the Mutual Economic Assistance were terminated after the fall of the socialist regime and most workers returned to their original countries. "Still here at 30 April 1993 under these agreements there 1100 people of Vietnamese nationality are still employed, as well as 210 citizens of Poland and 10 citizens of Angola." (Baršová at al. 2005, p. 219).

The period after 1989 was initially a lot different from the post-war immigration flows. Residents who had emigrated under socialism, reimmigrated back on the account of family ties, national sentiments and new economic opportunities. Foreign immigrants moved to the Czech Republic for essentially the same reasons (except national sentiment). They rather took advantage of the generosity of the old visas, linguistically and culturally close environment or family relationships and migration networks. Unlike the post-war period, the number of foreigners in the Czech Republic increased until 2008, despite a slight decline in 2000 (see figure 1). Since 2008, due to the economic crisis, the number of foreigners in the Czech Republic has decreased every year. 
Figure 1. Number of foreigners in the Czech Republic (share of expenditures in \%)

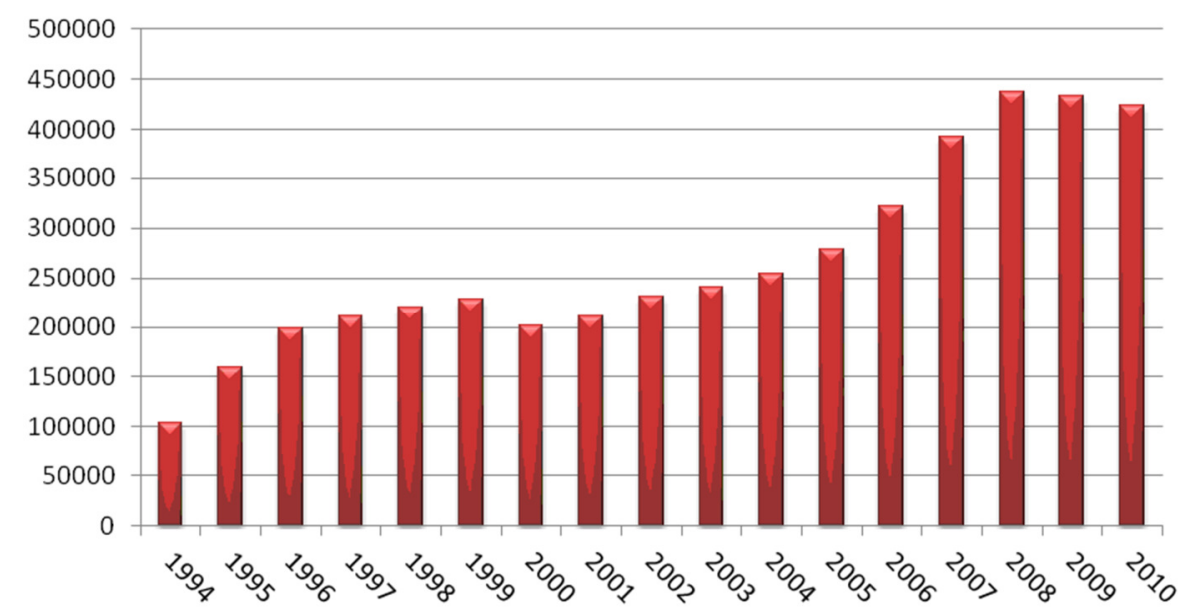

Source: CSO.

With the growth of unemployment in the mid-nineties, stricter foreign regulations came into force. This change in the immigration policy of the Czech Republic culminated in a restrictive new Aliens Act and Asylum Law (which came into force on 1 January 2000) as a response to the economic slowdown in 1997. Baršová and Barša describe the Aliens Act as establishing a completely new regime. "These changes have led to many problems for foreigners and the temporary freezing of immigration. Under the previous Act, immigrants could settle permanently only if they had been potential immigrant families who lived here permanently or in response to specific humanitarian considerations, whereas long-term stay or a work permit or business could lead to permanent settlement. The new law will allow all foreigners to apply for permanent residence after they have been here for ten years."(Baršová at al. 2005, p. 223).

Figure 2 illustrates the impact of immigration policy on immigration flows to the Czech Republic. In 2000, the new law came into force, which first led to an increase in the number of immigrants until 2003, when there was a slight decline. The immigration flows to the Czech Republic grew until its peak in 2007, and then there was a rapid decline due to the bad economic situation. 
Figure 2. Immigration flows of foreigners into the Czech Republic in the period 2001-2011

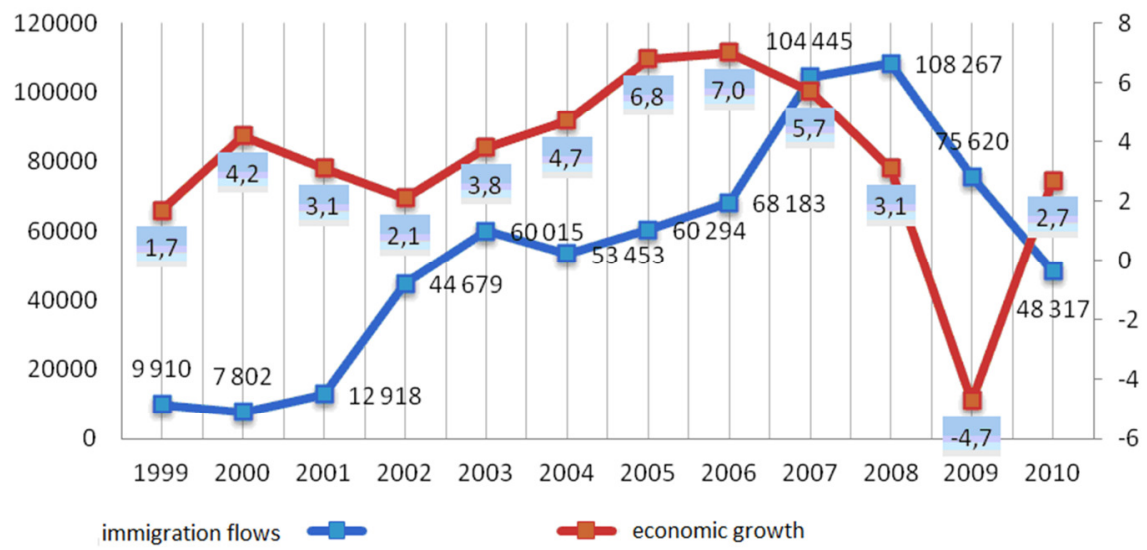

Source: CSO.

In 2000, the Czech Republic started its preparations for accession to the European Union and the harmonization of European law. In 2003, Directive 2003/109/EC came into force, concerning the status of thirdcountry nationals who are long-term residents. This Directive provides for the possibility of foreigners to request permanent residence after staying in the Czech Republic for 5 years (Council of the European Union 2012).

\section{State and Integration}

Integration is understood as an essential part of the immigration policy of the Czech government. The Ministry of the Interior has the coordinating role in the area of integration. The complexity of the issue requires the cooperation of different departments, namely integration policies involving the Ministry of Interior, Ministry of Labour and Social Affairs, Ministry of Education, Youth and Sports, Ministry of Industry and Trade, Ministry of Health, Ministry of Regional Development and the Ministry of Culture. In addition to the involvement of state authorities, integration also involves collaboration with non-profit organizations (NGOs). "The concept of Integration of Foreigners in the Czech Republic" and "State integration program" are the basic documents for integration and migration policies. 


\section{Libuše Macáková}

\section{The Concept of Integration of Foreigners in the Czech Republic}

The integration policy depends on the collaboration of all participants in the problem, to increase the efficiency of integration measures, awareness and building / operation of regional integration centers. For 2011, 10 million CZK were allocated in the national budget for integration, which were distributed among some participants in the process. This is a 15 million CZK less than in previous years, when the means provided for the integration of foreigners amounted to 25 million crowns per year. The target group for integration here consists mainly of third-country nationals legally residing in the territory of the Czech Republic. Through the integration process, these foreigners should acquire the knowledge of the Czech language, economic self-sufficiency and, ultimately, there should be improved relations between foreigners and companies. It is necessary to involve institutions at the local level, and to achieve participation of regions, municipalities, NGOs, etc.

An Integration Center was established to facilitate and streamline the integration of third-country nationals who are long-term or permanently residing in the Czech Republic. All centers are co-financed by the European Fund for the Integration of third country nationals. The centers are provided various kinds of services free of charge to, especially consulting and information activities through which candidates are provided with information such as the essentials for a stay in the Czech Republic, education, health care or housing options. Courses of the Czech language for foreigners are also organized, with varying degrees of knowledge. Foreigners can also use legal counseling, social counseling and interpreting services to each center. Another useful service are sociocultural courses, which are mainly for foreigners acquainted with the conditions of life in the Czech Republic in terms of culture and behavior in society.

The websites of integration centers, where clear materials providing basic information about important areas of interest to foreigners, are unquestionably of great benefit. These include material focused on the issue of residence, employment and education system or healthcare in the Czech Republic.

\section{State Integration Program}

This is a program specifically aimed at the integration of refugees into the Czech society and based on the Law on Asylum. The aim is to create the 
conditions for obtaining the knowledge of the Czech language, and to proprovide housing and assistance for refugees on the labor market. For this purpose, they organized free language courses to assist in finding housing, and assistance with finding employment. The implementation of the program also involves many non-governmental organizations, which are also provided with subsidies from the state budget. Inclusion in the program is voluntary, at the request of the asylum seeker.

\section{Education}

Education is the key area of integration. Foreigners are provided the aforementioned free Czech language courses, especially designed to break down language barriers and thereby facilitate the integration of people into the society. Education, of course, is not limited to efforts to teach incoming foreigners to communicate, but also includes comprehensive education of the children of foreigners, which is a group that needs the most education. Including foreign children to school reflects their educational background, knowledge of Czech and, of course, also age. There is an effort to provide education for children in such a way as to improve their knowledge and communication skills. At the same time, they must not be completely cut off from their parents, as that could lead to social isolation.

Under the Education Act, the Czech Republic is obliged to provide the Regional Office to children of citizens of EU Member States' Free preparation for integration into basic education, including teaching of the Czech language tailored to the needs of these pupils. It is also required to ensure as far as possible, in cooperation with the countries of origin of the pupil, that support teaching of the mother tongue and culture of the country of origin is coordinated with normal education in elementary school." For foreigners who come from third countries, however, such a possibility does not exist. There is a partial alternative for young children's pre-school education combined with the teaching of the Czech language. This is not a free solution, however, and foreigners must bear the expense. Other regional integration centers provide Czech lessons for the migrants from third countries, and such courses can be specifically targeted at minor foreigners. 


\section{Development Programs of the Ministry of Education}

To help in the integration of foreigners, there is an interesting development program "Free Czech language lessons tailored to the needs of foreign pupils from third countries", which helps to solve the problem previously mentioned. Its purpose is to provide subsidies to primary schools for partial or full coverage of costs associated with the teaching of Czech language to children from third countries. These tutorials are intended to facilitate the integration of these children into the Czech society by providing knowledge of local laws and customs, and overcoming socio-cultural barriers. Grants may be used to provide intensive language courses organized during the holidays or during the school year, provided, however, that the intended foreigners will be subject to compulsory school attendance and to be pupils of the school which provides course.

Pre-school education: Foreigners have access to pre-school education under the same conditions as Czech citizens. (in the case of aliens who are nationals of third countries, there is a need to remain in the country for at least 90 days.) Pre-school education can be very important for the integration of foreign children, as at the age of 4 to 6 years, children quickly adapt and quickly lose communication barriers (Šindelářová 2009). This makes it a useful and effective tool that can contribute to the integration of foreign children into society. The problem, however, can result in a high demand for preschool education in the Czech Republic, thanks to which schools may be forced to reject candidates.

Compulsory school attendance: In 2008, the Czech Republic enacted equal elementary school access to all children, regardless of the legality of residence to, so they cannot deny education to any child under any unjustified stay. Under this law, compulsory school attendance from the law applies to all citizens of the EU Member State or third country nationals who reside in the Czech Republic for more than 90 days. It equally applies to parties of international protection.

Secondary schools: For secondary school education, it is necessary to demonstrate the knowledge of the Czech language and legality of residence in the Czech Republic. This condition implies that the lack of command of the Czech language may prevent further study and the pursuit of education for young foreigners, and so their preparation for participation in Czech schools becomes more important.

Colleges: In order to study at university, it is necessary to have a complete secondary or vocational education. Foreign students can study at state Czech universities under the same conditions as students who are 
citizens of the Czech Republic. Those foreigners who want to study in some other language are required to pay for themselves.

\section{The Number of Foreigners Educated in the Czech Republic}

In the school year 2009/2010 over 60000 foreigners were studying at Czech schools - i.e. $2.9 \%$ and were thus $2.9 \%$ of students in the Czech Republic. The largest proportion of students came from Slovakia, which has significant representation at all levels of the educational system and an overwhelming majority of foreign students at Czech universities. The foreigners studying at Czech universities are mainly foreign students who came to the Czech Republic to study directly (i.e. many of them are not born to parents residing in the Czech Republic). This is especially true for the Slovak students, which is mainly due to the location of the two countries and almost non-existent language barrier. Among college students, the representation of foreigners is roughly about 8,8\% (Eurydice 2009/2010). The number of foreign children in Czech schools is steadily increasing, and this increase in the number of students throughout the school can be described as the most important, since the number of university students in the Czech Republic compared to the school year 2003/2004 more than doubled (Český statistický úrad 2009).

\section{Health Care}

Health care in the Czech Republic is available to all foreigners, but there are differences in how it is paid for. Health care may be covered by the insurance for foreigners, or on the basis of bilateral treaties, or in exceptional cases, can be paid for in cash.

Health Insurance is a form of insurance which is used to cover health care. Health insurance is mandatory for all foreigners permanently residing in the Czech Republic and foreign nationals residing in the Czech Republic for more than 90 days. It can be divided into public and commercial insurance, where public insurance is available for a selected group of foreigners and commercial insurance must be arranged by foreigners who are not covered by public insurance.

The public insurance provides foreigners with the same rights as everyone else, and care is paid for in the same range as for the domestic population. This type of insurance applies to foreigners with permanent 
residence or an employee with an employer based in the Czech Republic. This includes citizens of the EU Member States, who must either meet the aforementioned criteria, or must be employed in the Czech Republic, receiving benefits from previous employment or be family members of such individuals. Public insurance can also be provided for foreigners who have been granted international protection respectively in other specifically defined cases.

An interesting example is the case when two foreigners with public insurance and at the same time without permanent residence in the Czech Republic have a new child. For that child, the parents' insurance does not transfer in any way and it is thus necessary to insure through commercial insurance: this is usually only possible after birth and so the baby is uninsured at the time of birth. This problem must be resolved through the insurance policy of the mother who would cover this critical period of life. In connection with the necessity of commercial insurance for children, however, the insurance company can refuse to insure the child. This can occur precisely when the child is born with a serious problem, such as any handicapped child.

Commercial insurance is a form of insurance, which is required for foreigners, who are not covered by public health insurance and who stay in the Czech Republic for more than 90 days. This category includes selfemployed people or family members of foreigners-employees such as their children, etc. Travel insurance is the condition for granting a residence permit with a minimum indemnity limit of 60,000 euro.

The scope of healthcare covered may vary among different insurance companies and thus depends on the specific contract, but usually only necessary emergency care is included. Currently, comprehensive health insurance of foreigners (coverage range approaching public insurance) is offered by only two insurance companies: General Health Insurance Company and the Company Slavia.

International bilateral agreements are agreements between the Czech Republic and other states, under which the two states are bound to provide medical care to citizens of the other state. Mostly it is for necessary and urgent health care. In this case, health care is paid for by the state.

Reimbursement of health care in cash. If foreigners for some reason do not have health insurance, they must pay for the care received in cash, i.e. at their own expense. In the event of a serious health problem, however, this may not be the ideal solution, especially in the case of costly medical care. A foreigner with permanent residence may lose his residence permit if he is uninsured. 
These solutions (i.e. payment in cash) are thus particularly useful where the individual current insurance does not cover the care provided (e.g. some dental treatments, etc.). This form of payment is also frequently used by illegal migrants (Jelínková 2007).

The costs of care are significant and the value of care provided to foreigners in 2010 was CZK 588 million, the highest amount in the last years, see Table 1 (Uzis 2010/2011). The number of foreigners who use health care was about 79 500. These were mostly foreigners from Slovakia, Ukraine, Vietnam and Germany, and so, to a certain extent, this corresponds with the total number of migrants from given nationalities.

As can be seen from Table 1, the method of payment of health care costs varies mostly according to the nationality of foreigners. For citizens of Slovakia, 'Insurance abroad' probably derives from the general vicinity of the two countries and the ease of migration between them. Unlike the Slovaks, the citizens of Ukraine, pay for the reimbursement of health care mostly in cash. It should be noted that this distribution is gradually changing and that from 2009 there was an increase in contractual insurance in the Czech Republic.

Table 1. Method of payment of health care provided to foreigners in the Czech Republic in 2010 (in thousands of CZK)

\begin{tabular}{|l|r|r|r|r|r|r|}
\cline { 2 - 7 } \multicolumn{1}{c|}{} & \multicolumn{1}{c|}{ Total } & $\begin{array}{c}\text { Insuran } \\
\text { ce } \\
\text { in CR }\end{array}$ & $\begin{array}{c}\text { Internatio } \\
\text { nal } \\
\text { insurance }\end{array}$ & \multicolumn{1}{c|}{ Cash } & State & Unpaid \\
\hline Total & $\mathbf{5 8 7 ~ 5 5 9}$ & $\mathbf{1 5 4 ~ 2 8 0}$ & $\mathbf{1 7 9 6 5 6}$ & $\mathbf{1 7 2 ~ 1 4 8}$ & $\mathbf{1 6 ~ 9 3 0}$ & $\mathbf{6 4 5 4 5}$ \\
\hline $\begin{array}{l}\text { Average per } \\
\text { person }\end{array}$ & $\mathbf{7 , 3 8}$ & $\mathbf{7 , 1 5}$ & $\mathbf{1 2 , 0 7}$ & $\mathbf{5 , 0 3}$ & $\mathbf{4 , 7 8}$ & $\mathbf{1 1 , 7 7}$ \\
\hline Slovakia & 171329 & 42986 & 95945 & 18522 & 1365 & 12511 \\
\hline Ukraine & 72758 & 26774 & 2862 & 28397 & 1639 & 13085 \\
\hline Vietnam & 39781 & 22858 & 1905 & 11129 & 704 & 3185 \\
\hline Germany & 38755 & 4485 & 19985 & 11369 & 35 & 2882 \\
\hline
\end{tabular}

Source: Ihis $(2010,2011)$.

In the case of illegal immigrants, the provision of health care is problematic because they generally do not have health insurance. As a result, illegal immigrants must pay for health care from their own resources. Though the majority of health care for migrants is paid, there are two exceptions where they are treated even if they are unable to pay the costs. The provision of necessary and urgent health care is mandatory by 
law, regardless of the residence status of individuals. At the same time, health care providers are committed to the treatment of infectious diseases, which is quite logical, to avoid spreading disease to other people in the population.

\section{Non-governmental Non-profit Prganizations}

Non-profit organizations (NGOs) play an essential role in the integration of foreigners, and a range of services complement each other in many aspects of national immigration policy. These services primarily include providing information and free advice. Most of these organizations have a website which conveys a lot of information in several languages. Range, quality and timeliness of information are very different, but in principle, it is possible for migrants to find basic information without difficulty. A good example are www.domavcr.cz sites that are operated by the International Organization for Migration. Although there is a considerable amount of good information, even here there is some outdated information that could be misleading to the reader. The most reliable information can be found on the website of Czech ministries, especially the Ministry of Interior, Ministry of Labor and Cizinci.cz, where information is updated continuously. However, there is a problem for those migrants whose skills with computers are limited, or who do not have a computer or Internet access at all. This means that migrants may not know about the organizations that would be able to offer them assistance.

In addition to providing information via the Internet, the majority of non-profit organizations focus on specific types of activities. It outweighs the provision of social and legal counseling to migrants, and this is especially beneficial for those migrants who did not manage to find their way in the Czech law. Other practical help offered by organizations striving at integration is to provide courses in Czech language. This may include teaching and tutoring children for easy inclusion in Czech schools: associations META o.s. focuses especially on young migrants, and seeks to increase their chances of successful integration through education. This organization also provides educators with a wide range of information in relation to students from other countries. Another organization trying to help the integration of migrants and improve their language skills is the Center for Integration of Foreigners, which not only offers language courses, but also brings together volunteers willing to help foreigners become familiar with their new environment. 
Nonprofit organizations often offer assistance in dealing with the authorities. They also help in finding employment, providing interpreter services, and try to improve the awareness of foreigners to local culture and society. In some cases, they offer medical or psychological treatment. Among other things, it is not uncommon to provide leisure activities.

The project financing of these organizations comes from different sources. The most important include obtaining a grant from the European Fund for the Integration of third-country nationals, the European Social Fund and the state budget. It is, of course, also possible to obtain a variety of gifts and grants from sources such as embassies, international organizations or regions and municipalities. In 2010, the European Fund earmarked more than 58 million CZK for third country integration projects (including funds made available to regional integration centers) (Ministerstvo vnitra 2010).

A problem with non-government organizations may appear with their deployment throughout the Czech Republic and so a different approach to migrants residing in other parts of the country may be necessary. These organizations are active mainly in Prague and Central Bohemia. This fact led to the establishment of regional integration centers (Concept of Integration of Foreigners in the Czech Republic), to assist in integration. NGOs focus on many aspects of integration of immigrants; and in spite of the disadvantage that they are concentrated in certain areas only, it is possible to conclude that without them the integration of foreigners into Czech society would be much more difficult.

\section{Czech Society's Approach to Immigration}

Some people support immigration, others reject it and consider undesirable. These views are based on various factors such as the state of a country's economy, unemployment, the size of the current migration flows, the character of immigration and integration policy within the country or just the pure fear of change and "damage" to their own culture. The formation of a particular attitude is significantly effected by education, living conditions and by the age of the citizens. An important role in shaping the public opinion is played by the media, which tend to emphasize negative information. They can largely distort information about immigrants and encourage negative attitudes on immigration issues by creating fear of the presence of foreigners. 
According to research of the Center for Public Opinion Research (CVVM), more than half of Czechs have always considered the presence of foreigners in the Czech Republic as a problem. Surveys also show that half of the citizens of the Czech Republic consider the number of foreigners in the Czech Republic as too high. It can be said that the Czechs have a rather negative attitude to immigration. The survey by CVVM also shows that it is often older people (over 60 years), people with low education and those that indicate their standard of living as bad who have an anti-immigration attitude. In contrast, people with higher education and good living standards have a positive approach to immigration, which is in line with the statement in the International Migration Outlook 2010.

The CVVM survey of March 2009 includes views on foreigners residing permanently in the Czech Republic. Almost three quarters of respondents (74\%) are inclined to the view that foreigners are involved in the increase in crime. This statement cannot be denied, but it is necessary to point out that the crime rates among the Ukrainians, who make up nearly a third of long-term legally resident foreigners, are comparable to the Czech citizens. Many respondents were of the opinion that foreigners increase overall unemployment. This view was certainly influenced by the growth rate in a given period (at the turn of 2008 and 2009) and probably influenced the number of individuals claiming the increase in immigration to be a problem. We can assume that there are always some groups of people who will feel threatened by immigration and will perceive immigrants as a threat to their jobs and to their maintaining or improving their living conditions.

\section{Conclusions}

The number of immigrants in the Czech Republic is growing constantly, and despite some fluctuations, the most numerous are the Ukrainians, the Slovaks and the Vietnamese. There was some decline in the number of immigrants during the last three years, as a result of the economic crisis and government measures related to it. At the end of 2010 there were over 425000 immigrants in the Czech Republic with long-term or permanent residence, which is approximately 13000 fewer than in 2008. This decrease, however, can be regarded as temporary and immigration in the future will surely grow again. And so it is necessary to constantly improve and refine programs dealing with immigration and to seek to simplify and streamline the integration of immigrants into Czech society, since integration is directly linked to immigration. 
Among the most important areas of integration is education. The main problem is in adult immigrants' and their children's lack of knowledge of the Czech language, which can make it almost impossible for them to integrate into the Czech society. This problem can be solved by Czech language courses, which are held at the Center for Integration of Foreigners and many NGOs. Facilitating the study of children of immigrants is undoubtedly very important, not only in relation to their successful integration into society, but also because it is a form of investment that can be returned in adulthood, if they remain to work in the country.

The activities of the Czech Republic in the field of immigration and the integration of foreigners are certainly commendable and should be continued. For example, it is possible to highlight the establishment of the Centers for Integration, which are undoubtedly important in the Czech Republic. But it should be borne in mind that not all areas are fully managed and we can note a number of problems. These include, for example, lack of participation in government programs aimed at immigration, minor deficiencies in the preparation for children of third country nationals for entry into primary schools, and also some gaps in the provision of health care. There is thus undoubtedly still room for improvement. The Czech Republic should therefore seek to develop these policies further, and remember that a well-mastered immigration policy can only be beneficial. That is possible direction of future research not only for me, but for all economists who are concerned with the issues connected with the Czech labour market.

\section{References}

Adámek P., Macákova L. (2006), Rigidity of the Labour Markets of the EU and the migration [in:] New Theory of Economy and Management of Organization, Oeconomica, Praha.

Borjas G.J. (1999), Economic research on the determinants of immigration: lessons for the European Union, The World Bank, Washington.

Borjas G.J. (2008), Labour economics, McGraw-Hill/Irwin, Boston.

Český statistický úřad (2009), Mateřské, základní a střední školy, konzervatoře, vyšši odborné a vysoké školy - studujicí cizinci, 2003/04-2009/10, http://www.c zso.cz/csu/cizinci.nsf/t/2700322E8F/\$File/c06r01.pdf.

Drbohlav D., Lachmanová L. (2008), Nelegální ekonomické aktivity migrantů: Česko v evropském kontextu [in:] Možné přístupy k odhadu počtu nelegálních migrantů v Česku a zvláště v Praze,Karolinum, Praha.

Eurydice (2009/2010), Organizace vzdělávací soustavy České republiky 2009/2010 http://eacea.ec.europa.eu/education/eurydice/documents/eurybase/eurybase_full _reports/CZ_CS.pdf. 


\section{Libuše Macáková}

Hatton T.J., Williamson J.G. (2005), Global migration and the world economy: two centuries of policy and performance, MIT Press, Cambridge.

Héricourt J., Spielvogel G. (2010), International Migration Outlook: SOPEMI 2010 [in:] Public Opinions and Immigration: Individual Attitudes, Interest Groups and the Media, OECD Publishing, Paris.

Jelínková M. (2011), Př́stup (ne)legálních migrantů ke zdravotní péči, Migraceonline.cz, http://www.migraceonline.cz/e-knihovna/?x=1973899.

International labour migration: A rights-based approach (2010) [in:] International Labour Office, Geneva, http://www.ilo.org/public/libdoc/ilo/2010/110B09_59_ engl.pdf.

Jovanovic M.N. (2005), The economics of European integration: limits and prospects, Edward Elgar, Cheltenham.

Keeley B. (2009), International migration: the human face of globalization, Organization for Economic Co-operation and Developement, Paris

Meta (2010), Inkluzivní škola, Současnost: Předškolní a základní vzdělávání.

Ministerstvo vnitra ČR (2010), Realizované projekty EIF 2010, http://www.mvc r.cz/soubor/realizovane-projekty-2010-web-xls.aspx.

OECD (2010), International Migration Outlook: SOPEMI (2010), Paris.

Samers M. (2010), Migration, Routledge, Milton Park.

Schiller B.R. (2008), The economics of poverty and discrimination, Pearson Prentice Hall, Upper Saddle River.

Šindelářová J. (2009), Metodický portál inspirace a zkušenosti učitelů [in:] Začleňování žáků - cizinců do výuky v ZŠ, http://clanky.rvp.cz/clanek/c/z/719 1/ZACLENOVANI-ZAKU-\%E2\%80\%93-CIZINCU-DO-VYUKY-VZS.html/.

Úzis (2011), Čerpání zdravotní péče cizinci v roce 2010, http://www.uzi s.cz/rychle-informace/cerpani-zdravotni-pece-cizinci-roce-2010. 